Available online at www.sciencedirect.com

SCIENCE DIRECT

Forest Ecology and Management 208 (2005) 137-152
Forest Ecology and

Management

www.elsevier.com/locate/foreco

\title{
Forest production responses to irrigation and fertilization are not explained by shifts in allocation
}

\author{
David R. Coyle ${ }^{1}$, Mark D. Coleman* \\ USDA Forest Service-Savannah River, P.O. Box 700, Bldg. 772-1G, \\ Southern Research Station, New Ellenton, SC 29809, USA
}

Received 27 September 2004; received in revised form 22 November 2004; accepted 23 November 2004

\begin{abstract}
Production increases in intensively managed forests have been obtained by improving resource availability through water and nutrient amendments. Increased stem production has been attributed to shifts in growth from roots to shoot, and such shifts would have important implications for belowground carbon sequestration. We examined above and belowground growth and biomass accumulation and distribution in two eastern cottonwood clones and American sycamore receiving irrigation (I), fertilization (F), or irrigation + fertilization (IF) and compared with non-treated controls (C). Aboveground growth and biomass accumulation responded positively to both I and F in all genotypes. After three growing seasons, the largest trees were sycamore receiving the IF treatment, with a total mean annual biomass production of $9.4 \mathrm{Mg} \mathrm{ha}^{-1} \mathrm{yr}^{-1}$. Total cottonwood mean annual biomass production in both clones was $>5.0 \mathrm{Mg} \mathrm{ha}^{-1} \mathrm{yr}^{-1}$ in the IF treatment. Aboveground biomass production was 6.3 and $>3.1 \mathrm{Mg} \mathrm{ha}^{-1} \mathrm{yr}^{-1}$ for sycamore and cottonwoods, respectively. Total root mass fraction was lower in high resource treatments and declined as stands aged. To compare allocation in trees of equal size, we used allometric relationships between above and belowground tissue. Allometric relationships between woody perennial tissues rarely differed among treatments. Improved resource availability caused large increases in growth and consequently accelerated development, but it had little effect on belowground allocation that was not explained by development. Reports of shifting belowground allocation due to soil resource availability must account for developmental effects if they are to accurately evaluate direct impacts of soil resources.
\end{abstract}

(C) 2004 Elsevier B.V. All rights reserved.

Keywords: Biomass; Intensive management; Planatus occidentalis; Populus deltoides; Root mass fraction; Silviculture

\footnotetext{
* Corresponding author. Tel.: +1 803725 0513; fax: +18037250311 .

E-mail address: mcoleman01@fs.fed.us (M.D. Coleman).

${ }^{1}$ Present address: Department of Entomology, 345 Russell Laboratories, University of Wisconsin, Madison, WI 53706, USA.
}

\section{Introduction}

As the global need for fiber and wood products increases, traditional forest management practices may be unable to keep up with demand. Intensive forest management practices have great promise to supply the growing demand for fiber and wood 
products. These practices include the selection of superior genetic material, mechanical site preparation, competition, and pest control, irrigation, and fertilization (Dickmann and Stuart, 1983; Stanton et al., 2002; Stanturf et al., 2001). This forest technology also has important applications for bioenergy production (Kauter et al., 2003; Sedjo, 1997), reduction of $\mathrm{CO}_{2}$ emissions (Graham et al., 1992), the remediation of contaminated sites (Newman et al., 1997), or some combination of applications such growing bioenergy crops with wastewater irrigation or on former waste disposal sites (Aronsson and Perttu, 2001; Myers et al., 1996). The benefits generated by each of these applications result from the high production of intensively managed forest stands. Further increases in plantation production require examination of specific limiting factors at the stand level (Fox, 2000).

Nutrient and water stress are major factors limiting forest production, and both can be alleviated by intensive management practices. Higher fertility increases leaf area, nutrient concentration, and carbon assimilation rates and in turn, increases rates of carbon assimilation, and improves carbon availability and whole-plant growth (Ericsson et al., 1992; Harrington et al., 1997; Samuelson et al., 2001). Favorable water availability provides a bulk-flow pathway for nutrient uptake and maintains turgidity for growth and higher stomatal conductance for photosynthesis (Blake et al., 1996; Kozlowski et al., 1991; Kramer, 1983; Landsberg, 1986). Studies including both fertilization and irrigation across a wide range of tree genera (Populus, Platanus, Liquidambar, Picea, Eucalyptus, and Pinus) indicate that forest production is generally limited by nutrient availability, but that response to nutrient amendment is dependent upon adequate moisture availability (Linder, 1989; Lockaby et al., 1997; Samuelson, 1998). Under humid climatic conditions, intermittent rainfall is expected to supply adequate moisture to elicit a response to fertilization, yet additional moisture supplied by irrigation may maximize the fertilizer response even in humid regions with infrequent precipitation events. Understanding the relative importance of these growth-limiting factors will require direct comparisons.

Critical processes regulating growth during nutrient and water stress include uptake of these soil resources by root systems. Belowground biomass and production are generally thought to be lower than aboveground fractions under favorable conditions (Dickmann et al., 1996; Giardina et al., 2004; Kozlowski et al., 1991; Misra et al., 1998; Sands and Mulligan, 1990; Waring and Schlesinger, 1985). This observed shift from below to aboveground production has been proposed as an important cause of increased stem growth with intensive management (Axelsson and Axelsson, 1986; Cannell et al., 1988; Heilman et al., 1994; Misra et al., 1998). However, recent information suggests that resource-induced shifts in allocation may largely be due to accelerated development- that is, that fertilization and irrigation simply result in larger, developmentally advanced trees with inherently different relative belowground growth than that observed in trees grown without amendments (Coleman et al., 2004a; King et al., 1999). Separating the effect of development from resource-induced allocation requires sequential sampling so that comparisons can be made among developmentally similar trees rather than among chronologically similar ones (Drew and Ledig, 1980; Hunt, 1978). Such comparisons are rare in forest production experiments because of the difficulty sampling roots and making multiple observations in developmentally distinct stands. Intensively managed short-rotation forest stands provide model forests for addressing such questions.

This manuscript reports above and belowground response of eastern cottonwood (Populus deltoides Bartr.) and American sycamore (Planatus occidentalis L.) stands grown with two levels of irrigation and fertilization in an intensively managed forest plantation. We first hypothesized that tree growth in the humid southeastern US is limited more by nutrient availability than by water availability, and that the combined treatment would have an additive effect. Second, we hypothesized that biomass distribution would favor aboveground fractions, independent of developmental effects, with increasing resource availability.

\section{Materials and methods}

The site, plant materials, and experimental design are described in greater detail by Coleman et al. (2004b). 


\subsection{Site description and preparation}

The experiment was conducted at the U.S. Department of Energy Savannah River Site, a National Environmental Research Park located near Aiken, SC in the Carolina Sand Hill physiographic region $\left(33^{\circ} 23^{\prime} \mathrm{N}\right.$, $81^{\circ} 40^{\prime} \mathrm{E}$ ). The soil is predominately a Blanton sand, and there is a loamy subsoil at a depth of 120-200 cm across the site (Rogers, 1990). Previous vegetation was plantation pine with an oak understorey. All soil and debris from previous vegetation were homogenized to a depth of $30 \mathrm{~cm}$. Lime was applied at a rate of 3.4 $\mathrm{Mg} \mathrm{ha}^{-1}$ to increase the soil $\mathrm{pH}$ to 6.5 .

We chose a site with deep sandy soil and low endemic soil moisture and nutrient levels and employed rigorous pest control measures throughout the entire study. This approach enabled us to be confident that our results were not confounded with other factors, but were produced by water and nutrient amendments applied through the irrigation system.

\subsection{Plant material}

Five tree genotypes were included in this experiment. Here, we report results for three genotypes: two eastern cottonwood clones (ST66: Issaquena County, MS; S7C15: Brazos County, TX) and American sycamore (open pollinated mixed orchard seed). Two cottonwood clones were included to give a broader genetic representation of the species than is possible with a single clone. Crown Vantage Corp. (Fitler, MS) and Westvaco Corp. (Summerville, SC), provided the cottonwood cuttings and sycamore seedlings, respectively.

Bare-root 1-0 sycamore seedlings were hand planted during the first week of February 2000. Cottonwood cuttings were collected from stool beds in early January 2000 and held at $3.3{ }^{\circ} \mathrm{C}$ until planting. Cuttings were soaked for at least $48 \mathrm{~h}$ prior to planting during the second week of April 2000.

\subsection{Experimental design}

We planted trees at $2.5 \mathrm{~m} \times 3 \mathrm{~m}$ spacing in 0.22 ha plots. Each plot had a central 0.04 ha measurement plot with 54 trees and large end borders planted with additional trees, some of which were selected for destructive sampling. To avoid adjacent plot affects, there were at least two additional border rows $(7.5 \mathrm{~m})$ between harvested trees and adjacent treatment plots (Coleman et al., 2004b). We considered each species separately in a randomized complete block factorial design with irrigation and fertilization as factors. Within each block, the four treatment plots of a given species were grouped together to minimize withinblock site gradients. Treatments consisted of control (C), irrigation (I), fertilization (F), and irrigation + fertilization (IF). We used drip irrigation to apply $5 \mathrm{~mm}$ of water daily to meet evaporative demand. During the reporting period, average annual rainfall at the site was $809 \mathrm{~mm}$. An average of $551 \mathrm{~mm}$ of additional water was supplied to irrigated plots during each growing season. We applied fertilizer at rates of 40, 80, and $120 \mathrm{~kg} \mathrm{~N} \mathrm{ha}^{-1} \mathrm{yr}^{-1}$ in years 1,2 , and 3 , respectively. Fertilizer was increased annually in this manner to correspond with demand made by growing trees, and this application protocol has been shown to benefit tree growth and decrease $\mathrm{N}$ leaching and groundwater contamination (Axelsson and Axelsson, 1986; Van Miegroet et al., 1994). Annual fertilizer treatments were split among 26 weekly applications and applied with the drip irrigation system. Fertilizer application supplied enough water to apply liquid fertilizer and flush trickle tube lines ( $5 \mathrm{~mm}$ per week). Control plots received $5 \mathrm{~mm}$ water per week to maintain experimental consistency. Thus, non-irrigated plots (i.e., C and $\mathrm{F}$ ) received $130 \mathrm{~mm}$ of additional water annually. Treatments were applied from the first of April to the first of October during 2000-2002.

\subsection{Growth measurements}

Following the 2000-2002 growing seasons, we recorded basal diameter, height, and diameter at breast height $(1.37 \mathrm{~m})$ for all trees in the measurement plots. Basal diameter was recorded at $10 \mathrm{~cm}$ on all cottonwood trees to avoid residual error associated with stump taper. We based biomass measurements on basal diameter in 2000 and 2001, and on diameter at breast height in 2002 .

\subsection{Fine root biomass}

We sampled fine root $(<5 \mathrm{~mm})$ biomass at five random locations in each plot each November from 2000 to 2002 . A $4.9 \mathrm{~cm}$ diameter corer was used to 
remove samples at soil depths of $0-15,15-45$, and 45 $105 \mathrm{~cm}$ depths. Soil and non-root material was washed away from roots by elutriation (Gillison's Variety Fabrication Inc., Benzonia, MI). Live roots were then manually separated from dead organic matter, oven dried at $60{ }^{\circ} \mathrm{C}$ to a constant mass, and weighed to the nearest $0.01 \mathrm{mg}$.

\subsection{Dormant biomass}

Whole tree destructive biomass harvests were conducted yearly during dormancy. We sampled one or two trees per species per replicate plot. Sample trees were stratified based on diameter so that we included the entire size range within five trees sampled for each genotype by treatment combination.

For each sample tree, we separated aboveground biomass into branch and stem fractions. In 2000 and 2001, the entire tissue sample was collected for each tree. In 2002, we measured stem, branch, and coarse root fresh weights and removed representative subsamples to determine water weight. All tissues were dried to constant weight at $60{ }^{\circ} \mathrm{C}$ prior to weighing. Each year, bark was separated from the wood in a $5 \mathrm{~cm}$ segment at the top, middle, and bottom of each stem. We multiplied total stem weight by a unitless ratio of bark to wood dry weight to estimate total bark and wood biomass. Total dry biomass was then calculated by summing the tissue fractions.

We separated belowground biomass into stump and coarse root fractions. In 2000, a $1 \mathrm{~m} \times 1 \mathrm{~m}$ square centered on the stump was excavated to a depth of $30 \mathrm{~cm}$ (total soil volume excavated $=0.3 \mathrm{~m}^{3}$ ). In 2001 and 2002, stumps were removed using a mechanical tree spade (model TS34C, Bobcat Co., West Fargo, $\mathrm{ND})$. Soil removed was a $1 \mathrm{~m}$ diameter $\times 0.69 \mathrm{~m}$ deep cone with sides angled at $30^{\circ}$ (total soil volume $\left.=0.18 \mathrm{~m}^{3}\right)$. Coarse roots $(>5 \mathrm{~mm}$ diameter $)$ were separated from the main stump. In 2000 and 2001, the main stump was dried to a constant temperature and weighed. In 2002, we measured fresh weight of the stump and removed a representative subsample to determine water weight. To estimate peripheral coarse root growth in the remainder of each harvested tree's growing space, we excavated three $0.188 \mathrm{~m}^{2}$ areas to $30 \mathrm{~cm}$ depth. Random sample areas were chosen in each of three locations within the tree growing space: (1) along tree rows (under trickle tube), (2) perpendicularly between tree rows, and (3) diagonally between trees. There were up to eight random sample areas to choose from within each of these three locations. No roots with diameter greater than $5 \mathrm{~mm}$ were observed entering depths below $30 \mathrm{~cm}$. All coarse roots collected in each of the peripheral sample areas were included in the sample without regard to tree of origin. Root biomass estimation by sampling in this manner has been shown to be comparable to those obtained by whole-tree excavation (Resh et al., 2003).

\subsection{Leaf biomass}

In 2000, we calculated leaf biomass from leaf length to leaf weight relationships (Coleman et al., 2004b). In 2001 and 2002, we measured leaf biomass via destructive tree harvests conducted in early September. Sample trees were stratified based on diameter. Six (2001) or four (2002) trees were chosen that encompassed the entire range of diameters for each genotype by treatment combination. Leaves were separated and dried at $60{ }^{\circ} \mathrm{C}$ to constant weight.

\subsection{Biomass calculations and statistical analysis}

To estimate leaf, bark, wood, branch, stump, and coarse root biomass for each tree, we used power functions with diameter as the independent variable (Parresol, 1999; Ter-Mikaelian and Korzukhin, 1997). We calculated individual tree biomass values based on diameter, summed the biomass values for all measurement plot trees, and divided by plot area to determine plot averages. Fine root biomass for each plot was calculated from fine root harvest data. Shoot biomass was the sum of branch, bark, and wood biomass. Root biomass was the sum of stump, coarse root, and fine root biomass. Root mass fraction (RMF) was calculated as root biomass/total biomass.

We used plot means to analyze biomass components. This method adequately accounts for variance between plot means, but eliminates variance among sample trees used to develop regression equations (Parresol, 1999). Therefore, within-plot variance among trees used in the ANOVA may have been less than what actually existed among sample trees. However, because we have a large number of trees per plot $(n=54)$, we can assume that individual tree variance equilibrates according to the central limit 
theorem and the mean accurately represents the plot as the experimental unit.

We conducted analyses separately for each tree genotype. Diameter, height, biomass for various tissue components, and root mass fraction were analyzed using a repeated measures analysis in a randomized complete block design (Proc Mixed, SAS Inc. Cary, NC, USA). We used orthogonal contrasts to examine the individual effects of $\mathrm{I}, \mathrm{F}$, and the $\mathrm{I} \times \mathrm{F}$ interaction, and compared treatment means using the Tukey's HSD test.

We used allometric relationships to separate resource availability and plant-development effects on biomass allocation (Coleman et al., 2004a). This approach is possible if sequential harvests are taken, as in our annual biomass sampling (Hunt, 1978). We used the model:

$\ln y=a+k \ln x$

where $x$ and $y$ are tissue components being compared, $a$ is the $y$ intercept, and the slope $k$ is the allometric coefficient. If $k$ is equal among treatments, any changes in allocation are explained by development (Hunt, 1978). A larger $k$ indicates a greater root fraction when the belowground fraction is regressed as the dependent variable of the aboveground fraction. We used log-transformed data, set treatment as the class variable, and employed analysis of covariance to check for differences among treatments (Gebauer et al., 1996; King et al., 1999). Analysis of covariance involved fitting the model described in Eq. (1) by the treatment class variable. When treatment alters allocation, that is, if $k$ differs among treatments, a significant interaction occurs between the covariate and the treatment factor (Kleinbaum and Kupper, 1978). We also used covariate analysis to compare RMF versus tree size relationships among treatments. Treatments differences in $k$ and the relationships of RMF versus tree size were tested using the estimate statement in SAS Proc Mixed (Littell et al., 1996).

\section{Results}

\subsection{Growth measurements}

All three genotypes responded positively to I and F treatments. The individual effects of I and F produced

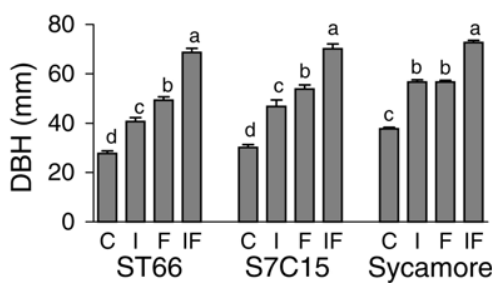

Fig. 1. Mean + S.E. $(n=3)$ diameter after three growing seasons. Treatments consisted of control (C), irrigation (I), fertilization (F), and irrigation + fertilization (IF). Means sharing a letter within a genotype are not significantly different (Tukey's HSD from repeated measures analysis, $\alpha=0.05$ ).

significant diameter increases in all genotypes (Fig. 1) $(P<0.002)$. A weak $\mathrm{I} \times \mathrm{F}$ interaction occurred for sycamore $(P<0.09)$ but not for the two cottonwood clones $(P>0.51)$. Sycamore responded more to $\mathrm{F}$ without I than with it in the first 2 years. Treatment effects on height growth were identical to treatment effects on diameter (data not shown). Cottonwood height ranged from 1.5 to $7.6 \mathrm{~m}$ and sycamore from 1.6 to $7.1 \mathrm{~m}$.

\subsection{Biomass accumulation}

Biomass in each tissue fraction was well correlated with diameter. Information describing equations used for calculating biomass from the 2002 data are provided in Appendix A. The exponent in the power equation determines the amount of change in biomass with a change in diameter. On average, shoot exponents were $26 \%$ greater than root exponents.

Mean annual biomass production after three growing seasons differed between species. Sycamore produced nearly twice as much total biomass as either cottonwood clone growing with the same treatment (Table 1). Each cottonwood clone produced roughly the same amount of biomass. Biomass accumulation rates increased each year in all genotypes receiving the $\mathrm{F}$ and IF treatments, while biomass accumulation was greatest in the second growing season in trees that received $\mathrm{C}$ and I treatments, largely due to belowground production. Cottonwood total annual biomass increment across all treatments ranged from 0.4 to 1.4 $\mathrm{Mg} \mathrm{ha}^{-1}$ in year 1 and 1.2 to $9.1 \mathrm{Mg} \mathrm{ha}^{-1}$ in year 3. Sycamore total annual biomass increment ranged from 1.1 to 3.5 in year 1 and 2.4 to $17.2 \mathrm{Mg} \mathrm{ha}^{-1}$ in year 3 . Sycamore receiving the IF treatment nearly 
Table 1

Mean annual production $\left(\mathrm{Mg} \mathrm{ha}^{-1} \mathrm{yr}^{-1}\right)$ of three tree genotypes after three growing seasons

\begin{tabular}{clll}
\hline & Aboveground & Belowground & Total \\
\hline ST66 & & & \\
C & $0.6 \pm 0.1$ & $0.6 \pm 0.1$ & $1.2 \pm 0.2$ \\
I & $1.1 \pm 0.4$ & $1.0 \pm 0.2$ & $2.1 \pm 0.5$ \\
F & $1.8 \pm 0.4$ & $1.6 \pm 0.2$ & $3.4 \pm 0.6$ \\
IF & $3.1 \pm 0.5$ & $2.0 \pm 0.2$ & $5.1 \pm 0.7$ \\
S7C15 & & & \\
C & $0.8 \pm 0.1$ & $0.8 \pm 0.1$ & $1.5 \pm 0.2$ \\
I & $1.7 \pm 0.5$ & $1.1 \pm 0.1$ & $2.8 \pm 0.6$ \\
F & $1.8 \pm 0.2$ & $1.2 \pm 0.2$ & $3.0 \pm 0.2$ \\
IF & $3.2 \pm 0.5$ & $1.8 \pm 0.2$ & $5.0 \pm 0.6$ \\
Sycamore & & & \\
C & $1.5 \pm 0.1$ & $1.1 \pm 0.1$ & $2.6 \pm 0.2$ \\
I & $3.5 \pm 0.4$ & $2.1 \pm 0.1$ & $5.7 \pm 0.4$ \\
F & $3.3 \pm 0.2$ & $2.3 \pm 0.1$ & $5.7 \pm 0.1$ \\
IF & $6.3 \pm 0.9$ & $3.1 \pm 0.2$ & $9.4 \pm 0.7$ \\
\hline Da & & & \\
\hline
\end{tabular}

Data are means \pm S.E. $(n=3)$.

doubled it's existing biomass in the third year, accumulating $8.7 \mathrm{Mg} \mathrm{ha}^{-1}$ in 2001 to over $17 \mathrm{Mg} \mathrm{ha}^{-1}$ in the 2002 growing season.

Resource amendments had significant effects on total biomass (Table 2, Fig. 2). Both species showed strong positive responses to fertilizer in all years. For ST66, the positive response to I was $66 \%$ of that of the response to F. For S7C15 and sycamore, the response to I was equal to the response F. In all genotypes, trees receiving the IF treatment accumulated significantly more biomass than those receiving all other treatments (Fig. 2).

Above and belowground biomass by the third year were equal in ST66 ( $t$-test, $P>0.1$ ), whereas aboveground biomass was greater than belowground in S7C15 and sycamore ( $t$-test, $P<0.01$ ). All genotypes receiving the IF treatment showed greater above- and belowground biomass than those receiving $\mathrm{C}, \mathrm{I}$, and $\mathrm{F}$ treatments (Fig. 2). In most instances, I and $\mathrm{F}$ main effects on biomass components were significant and there were few $\mathrm{I} \times \mathrm{F}$ interactions (Table 2). Responses to $\mathrm{F}$ were usually stronger than responses to I, but this was not the case with branch, coarse root, and total root biomass responses in S7C15. ST66 branch biomass and cottonwood fine root biomass were the only fractions not affected by I. There were significant $\mathrm{I} \times \mathrm{F}$ interactions on coarse root and sycamore stump biomass in ST66. Irrigation had a greater effect on
Table 2

Significance levels for biomass fractions after 3 years of resource amendment treatments

\begin{tabular}{|c|c|c|c|c|}
\hline \multirow[t]{2}{*}{ Variable } & \multirow[t]{2}{*}{ Source } & \multicolumn{3}{|c|}{ Significance level } \\
\hline & & ST6 $^{\mathrm{a}}$ & S7C15 & Sycamore \\
\hline \multirow[t]{3}{*}{ Branch } & Irr & ns & ***** & ******* \\
\hline & Fert & ****** & $* *$ & $* * * *$ \\
\hline & Irr $\times$ Fert & ns & ns & ns \\
\hline \multirow[t]{3}{*}{ Bark } & Irr & * & ** & $* * * * *$ \\
\hline & Fert & **** & **** & $* * * *$ \\
\hline & Irr $\times$ Fert & ns & ns & ns \\
\hline \multirow[t]{3}{*}{ Wood } & Irr & **** & **** & ****** \\
\hline & Fert & $* * * * *$ & **** & $* * * *$ \\
\hline & Irr $\times$ Fert & ns & ns & ns \\
\hline \multirow[t]{3}{*}{ Stem } & Irr & *** & **** & ****** \\
\hline & Fert & $* * * * *$ & $* * *$ & ****** \\
\hline & Irr $\times$ Fert & ns & ns & ns \\
\hline \multirow[t]{3}{*}{ Total shoot ${ }^{\mathrm{b}}$} & Irr & ** & **** & $* * * *$ \\
\hline & Fert & ****** & ***** & $* * * * *$ \\
\hline & Irr $\times$ Fert & ns & ns & ns \\
\hline \multirow[t]{3}{*}{ Stump } & Irr & *** & **** & $* * * *$ \\
\hline & Fert & ***** & $* * * * *$ & $* * * *$ \\
\hline & Irr $\times$ Fert & ns & ns & ***** \\
\hline \multirow[t]{3}{*}{ Coarse root } & Irr & * & $* * * * *$ & * \\
\hline & Fert & **** & $* * *$ & $* * * *$ \\
\hline & Irr $\times$ Fert & * & ns & ns \\
\hline \multirow[t]{3}{*}{ Fine root } & Irr & ns & ns & * \\
\hline & Fert & *** & ns & $\mathrm{ns}$ \\
\hline & Irr $\times$ Fert & ns & ns & ns \\
\hline \multirow[t]{3}{*}{ Total $\operatorname{root}^{\mathrm{c}}$} & Irr & * & $* * * * *$ & ***** \\
\hline & Fert & ** & $* * *$ & $* * * *$ \\
\hline & Irr $\times$ Fert & ns & ns & * \\
\hline \multirow[t]{3}{*}{ Total biomass ${ }^{\mathrm{d}}$} & Irr & $* *$ & $* * * *$ & $* * * *$ \\
\hline & Fert & $* * * *$ & $* * * *$ & $* * * * *$ \\
\hline & Irr $\times$ Fert & ns & ns & ns \\
\hline
\end{tabular}

${ }^{\mathrm{a}}$ Significance of analysis of variance factor: ns, not significant; ${ }^{*} P \leq 0.05 ;{ }^{* *} P \leq 0.01 ;{ }^{* * *} P \leq 0.001 ;{ }^{* * * *} P<0.0001$.

$\mathrm{b}$ Total shoot $=$ branch + bark + wood.

c Total root $=$ stump + coarse root + fine root.

d Total biomass $=$ total shoot + total root.

sycamore belowground biomass accumulation without F.

Wood and fine root biomass accounted for the largest portions of above and belowground biomass, respectively (Fig. 2). Wood represented from 36 to $56 \%$ of aboveground biomass in cottonwood and from 54 to $61 \%$ of aboveground biomass in sycamore. Fine root biomass was from 48 to $63 \%$ of belowground 


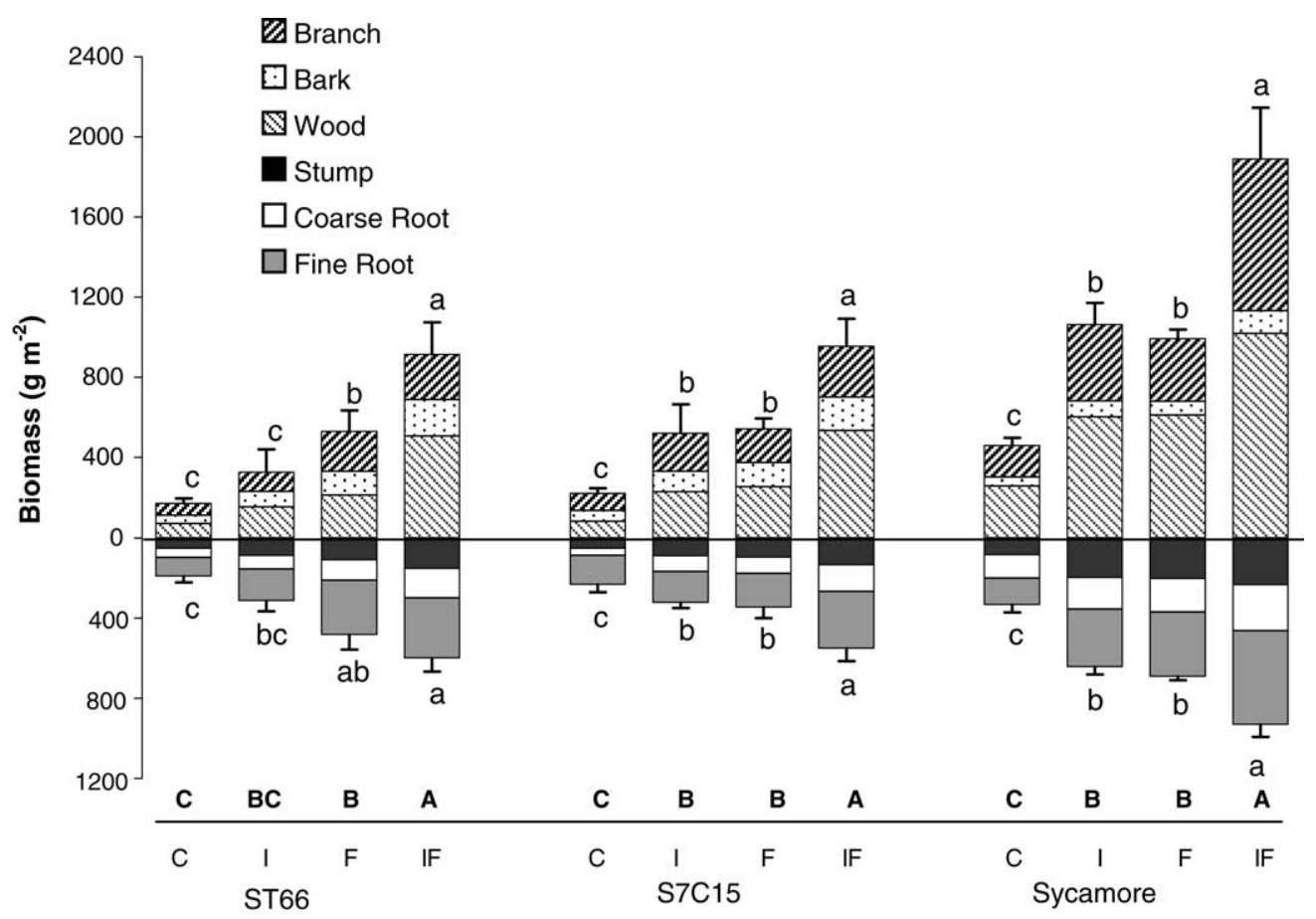

Fig. 2. Total dormant biomass after three growing seasons of three tree genotypes receiving irrigation and fertilization treatments $(n=3)$. Treatments consisted of control $(\mathrm{C})$, irrigation $(\mathrm{I})$, fertilization $(\mathrm{F})$, and irrigation + fertilization (IF). Zero on the $Y$-axis represents the groundline. S.E. bars and significance letters refer to shoot (above 0) and root (below 0). Means sharing a letter within a genotype are not significantly different (Tukey's HSD from repeated measures analysis, $\alpha=0.05$ ). Lower case letters and standard error bars above the columns are for total aboveground biomass; those below the columns are for total belowground biomass. Capital letters above the $X$-axis refer to total biomass.

biomass in cottonwood and from 40 to $51 \%$ of belowground biomass in sycamore.

\subsection{Biomass distribution}

Root mass fraction (RMF) declined significantly with stand age and with increasing resource availability (Fig. 3). Treatment responses were consistent between years (no significant treatment $\times$ year interactions). Cottonwood RMF responded more to treatments than did sycamore RMF. ST66 RMF responded more to $\mathrm{F}$ than to $\mathrm{I}$, sycamore responded to $\mathrm{I}$, but not to $\mathrm{F}$, and no genotype showed $\mathrm{I} \times \mathrm{F}$ interactions. RMF, averaged across all genotypes, declined 30\% from the first to the third year harvest, and it was 19\% lower for the IF treatment than for the $\mathrm{C}$ treatment. Thus, a lower proportion of biomass growth occurred belowground both as trees developed and in response to increased soil resource availability.
The magnitudes of RMF changes with development and treatment were similar.

Treatment effects not explained by development can be identified by testing for differences in $k$, the allometric constant. There were strong linear relationships between total root biomass and both shoot and total biomass $\left(R^{2}>0.89, P<0.0001\right)$. Stump, coarse root and fine root fractions were similarly related to shoot or total biomass $\left(R^{2}>0.69, P<0.0001\right)$. Several comparisons showed treatment differences in $k$ for both perennial and ephemeral tissues (Table 3). Fertilization was the factor that affected $k$ most strongly. Although we had hypothesized otherwise, aboveground biomass accumulation seldom exceeded belowground biomass accumulation (i.e., had lower $k$ ) with increased resource availability. There were treatment effects on $k$ for 7 of 15 comparisons between various root and aboveground components; however, fertilization lowered $k$ in fewer than half of 


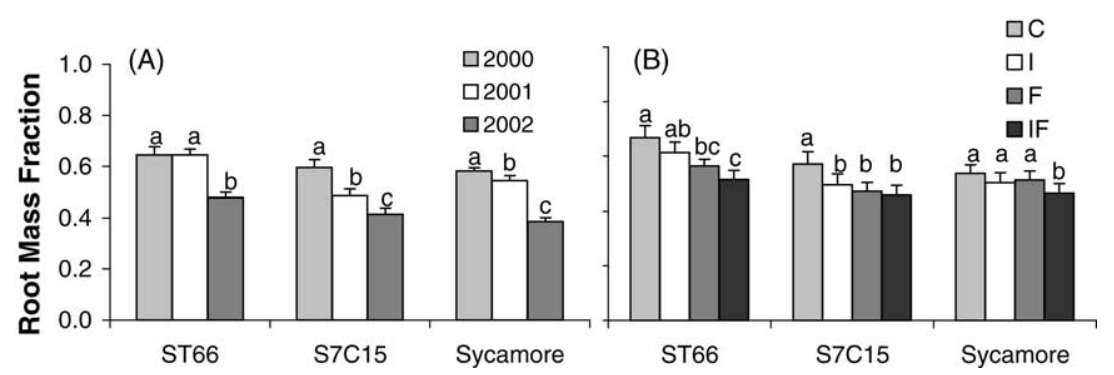

Fig. 3. Root mass fraction for (A) each of 3 years $(n=9)$ and (B) in response to irrigation and fertilization treatments $(n=12)$. Treatments consisted of control (C), irrigation (I), fertilization (F), and irrigation + fertilization (IF). Means sharing a letter within a species are not significantly different (Tukeys HSD, $\alpha=0.05$ ).

those comparisons. Coarse roots versus shoot in both S7C15 and sycamore were the only perennial tissue comparisons in which $k$ decreased due to fertilization. Most comparisons between perennial fractions had higher $k$ with higher resources.

Treatment patterns for $k$ between ephemeral fine root and leaf tissue differed for each genotype

Table 3

Allometric coefficient, $k^{\mathrm{a}}$, for various root and stem components compared among treatments for each of the genotypes

\begin{tabular}{lllll}
\hline & & ST66 & S7C15 & Syc \\
\hline Root vs. shoot & C & $0.60 \mathrm{~b}$ & 0.62 & 0.73 \\
& I & $0.78 \mathrm{ab}$ & 0.82 & 0.73 \\
& F & $0.90 \mathrm{a}$ & 0.73 & 0.57 \\
Fine root vs. shoot & IF & $0.82 \mathrm{a}$ & 0.67 & 0.71 \\
& C & $0.45 \mathrm{~b}$ & 0.59 & 0.77 \\
& I & $0.90 \mathrm{ab}$ & 0.81 & 0.85 \\
Coarse root vs. shoot & F & $1.31 \mathrm{a}$ & 0.72 & 0.85 \\
& IF & $1.02 \mathrm{a}$ & 0.59 & 0.92 \\
& C & 0.92 & $0.74 \mathrm{ab}$ & $0.69 \mathrm{a}$ \\
Stump vs. shoot & I & 0.76 & $0.88 \mathrm{a}$ & $0.59 \mathrm{ab}$ \\
& F & 0.73 & $0.64 \mathrm{~b}$ & $0.23 \mathrm{c}$ \\
& IF & 0.67 & $0.69 \mathrm{ab}$ & $0.51 \mathrm{~b}$ \\
& C & 0.63 & $0.65 \mathrm{~b}$ & 0.66 \\
Fine root vs. leaf & I & 0.67 & $0.78 \mathrm{a}$ & 0.70 \\
& F & 0.69 & $0.76 \mathrm{a}$ & 0.66 \\
& IF & 0.70 & $0.77 \mathrm{a}$ & 0.66 \\
& C & $0.31 \mathrm{~b}$ & $0.44 \mathrm{ab}$ & 0.66 \\
& I & $0.23 \mathrm{~b}$ & $0.72 \mathrm{a}$ & 0.67 \\
& F & $1.06 \mathrm{a}$ & $0.54 \mathrm{ab}$ & 0.55 \\
& IF & $0.27 \mathrm{~b}$ & $0.27 \mathrm{~b}$ & 0.82 \\
\hline
\end{tabular}

Values of $k$ followed by the same letter are not significantly different.

${ }^{a}$ The allometric coefficient, $k$, is the slope of the linear model: $\ln y=a+k \ln x$, where $x$ and $y$ are tissue components being compared and $a$ is the $y$ intercept.
(Table 3). For ST66, $k$ was higher with $\mathrm{F}$ than with other treatments; for S7C15, $k$ was lowest with IF; for sycamore, no treatment differences in $k$ were detected. For both perennial and ephemeral tissues, the treatment effect was minor compared to developmental effects.

Treatment comparisons of RMF can also be considered as plants develop (Poorter and Nagel, 2000). As plants increased in size, RMF declined (Fig. 4, $P<0.014$ ). However, this relationship did not differ among treatments $(P>0.208)$. This comparison does not indicate that RMF decreased with higher resource availability; rather, it shows that RMF declined with development.

\section{Discussion}

\subsection{Effects of resource amendments on production}

Improved resource availability led to increased growth in all tree genotypes (Figs. 1 and 2). Results for cottonwood diameter support the hypothesis that nutrient availability limits growth more than water availability does at this humid southeastern US site because the response to fertilization was greater than the response to irrigation. However, for diameter in sycamore and for biomass in both $\mathrm{S7C} 15$ and sycamore, the response to fertilization was equal to that of irrigation, indicating that these two genotypes were equally dependent on each resource. Nonetheless, the combined treatment produced the greatest growth in all genotypes. For total root, the response to IF was additive, that is approximately equal to the sum of the response to I and F. However, aboveground 

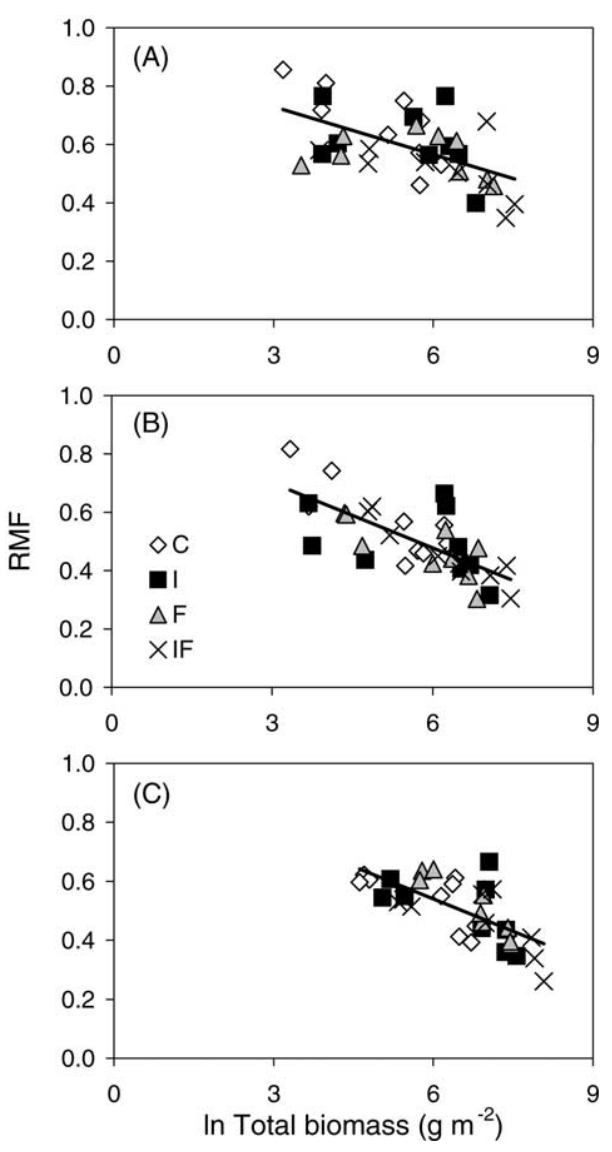

Fig. 4. Root mass fraction (RMF) as a function of total biomass. Treatments consisted of control (C), irrigation (I), fertilization (F), and irrigation + fertilization (IF). Least-squared linear regression lines $(P>0.0135)$ are shown for each species: A, ST66; B, S7C15; $\mathrm{C}$, Sycamore. Each point is for individual field plots measured in each of the 3 years.

response to IF was greater than the sum of the response to I and F.

Our irrigation treatment results agree with those of other studies showing the positive effect of increased water availability on Populus (Blake et al., 1996; Dickmann et al., 1996; Gebre and Kuhns, 1991). Cottonwoods grown in arid environments have shown more than a three-fold volume increase in response to irrigation (Shock et al., 2002), while those grown in humid environments may not respond to irrigation alone (Lockaby et al., 1997). Similarly, Eucalyptus species grown in drier environments exhibit strong positive growth responses to increased water availability (Pereira et al., 1989; Reed and Tomé, 1998;
Tomé et al., 1994), while those grown in humid environments often do not respond positively to irrigation (Adams et al., 2003; Misra et al., 1998). In contrast, one study showed that production of sycamore in the humid southeastern US increased with greater water availability (Lockaby et al., 1997). Their response was probably due to the relatively droughty soil type (storing $91 \mathrm{~mm}$ at field capacity), not low precipitation, because only two of four treatment years were droughty ( $>85 \%$ normal precipitation).

Increased soil moisture availability had a positive effect on production in our study despite the humid environment. Soils at this location were sandy and well drained, and had a low water storage capacity. These soils store $31 \mathrm{~mm}$ of water in the upper $45 \mathrm{~cm}$, a 5-6 day supply during peak evaporative demand. The lower soil profile $(45-105 \mathrm{~cm})$ stores $45 \mathrm{~mm}$, enough water for an additional 8-9 days (Coleman et al., 2004b). During the three growing seasons of this study, precipitation events supplying more than $30 \mathrm{~mm}$ of water occurred on average every 36 days, which suggests that the frequency of natural rain events was not adequate to prevent soil moisture deficits.

The effects of fertilization on growth were larger than those obtained in other experiments. Increases in Populus tree growth and production can be attained using fertilization, especially in poor soils (Hansen et al., 1988). Fertilizer amendments have resulted in Populus production increases of $21 \%$ in Washington and Vancouver Island, Canada (Brown and van den Driessche, 2002; Heilman and Xie, 1993), and 62\% in Maine (Czapowskyj and Safford, 1993). Other fertilizer studies have shown gains of $45 \%$ in Tennessee (Thornton et al., 2000) and 33\% in Mississippi (Blackmon, 1977), further illustrating the beneficial effect of plantation fertilization. In our study, fertilization led to 200,125 , and $120 \%$ production increases aboveground in ST66, S7C15, and sycamore, respectively (Figs. 1 and 2). Our relatively large fertilizer response reflects low soil nutrient availability at our site. Plantations on high quality soil, however, may not benefit to the same extent from increased fertilization (Hansen et al., 1988; McLaughlin et al., 1987).

Biomass components in all three genotypes in this study showed strong positive responses to IF. ST66, $\mathrm{S} 7 \mathrm{C} 15$, and sycamore trees receiving the IF treatment 
were 315,229 , and $257 \%$ larger than controls, respectively. In other studies, similar treatments increased stem volume by $92 \%$ in trembling aspen (van den Driessche et al., 2003), 80\% in sycamore (Lockaby et al., 1997), 657\% in sweetgum (Samuelson et al., 2001), and up to $284 \%$ in eucalyptus (Pereira et al., 1989; Reed and Tomé, 1998), demonstrating a universal positive effect of combined irrigation and fertilization on hardwood tree production. Our IF treatment results agree with those reported by Linder (1989), who demonstrated that moisture is required to optimize the fertilizer response, suggesting that both moisture and nutrients are limiting on many sites.

The largest sycamore trees in our study had nearly double the total biomass of the largest cottonwood trees (Fig. 2). Sycamore stem biomass was nearly twice that of the largest cottonwood clone, S7C15, even though average stem volume was the same in these genotypes $\left(3.74 \mathrm{dm}^{3}\right)$, specific densities reported for sycamore are 8-36\% greater than cottonwood (Chow et al., 1995). Sycamore also had many more branches than did either cottonwood, with the result that branch biomass was up to $70 \%$ greater (Fig. 2). These factors combine to cause overall greater total biomass in sycamore.

Mean annual aboveground production for ST66 and S7C15 grown with irrigation and fertilization was 3.1 and $3.2 \mathrm{Mg} \mathrm{ha}^{-1} \mathrm{yr}^{-1}$, respectively (Table 1). These values are greater than aboveground production rates in some Populus studies in the Lake States $(2.5 \mathrm{Mg}$ $\mathrm{ha}^{-1} \mathrm{yr}^{-1}$ at age 3, Netzer et al., 2002) but lower than those in stands in the Mississippi River Valley (7.7 and $6.0 \mathrm{Mg} \mathrm{ha}^{-1} \mathrm{yr}^{-1}$ at age 3 and 4, respectively, Francis and Baker, 1981; Switzer et al., 1976) and the Pacific Northwest $\left(9.7 \mathrm{Mg} \mathrm{ha}^{-1} \mathrm{yr}^{-1}\right.$ at age 4, Heilman and Xie, 1993). However, fertilizer rates $\left(500 \mathrm{~kg} \mathrm{~N}^{-1}\right.$ $\mathrm{yr}^{-1}$ ) and stocking (2222 trees ha ${ }^{-1}$ ) were much higher in the Pacific Northwest study, and the Mississippi River Valley study was conducted on better soils. Biomass production increases as stocking density increases in intensively managed forest plantations even though individual stems are smaller (Bernardo et al., 1998; DeBell et al., 1996). For instance, when eucalyptus was grown for 41 months at 2.7 times the density, individual stem diameter decreased by $22 \%$, while aboveground stand biomass increased 29\% (Bernardo et al., 1998). Therefore, it is difficult to make valid comparisons between our findings and those from studies with high stocking densities.

Sycamore growth rates in our study are relatively high (Table 4). Mean annual aboveground production of trees receiving fertilization and irrigation was $6.3 \mathrm{Mg} \mathrm{ha}^{-1} \mathrm{yr}^{-1}$ (Tables 1 and 4). Third year diameter and height in our plantation equaled those reported from a 4-year fertilized and irrigated study in Alabama (Lockaby et al., 1997). High stocking density probably contributed to increased production in other studies (Table 4).

Belowground biomass responded positively to increased resource availability (Table 1, Fig. 2). Total

Table 4

Reported aboveground production of intensively managed sycamore in the southeastern US

\begin{tabular}{lcccll}
\hline State & $\begin{array}{l}\text { Fertilization } \\
\left(\mathrm{kg} \mathrm{N} \mathrm{ha}^{-1} \mathrm{yr}^{-1}\right)\end{array}$ & $\begin{array}{l}\text { Production } \\
\left(\mathrm{Mg} \mathrm{ha}^{-1} \mathrm{yr}^{-1}\right)\end{array}$ & $\begin{array}{l}\text { Stocking } \\
\left(\operatorname{trees~ha~}^{-1}\right)\end{array}$ & $\begin{array}{l}\text { Stand age } \\
(\text { years })\end{array}$ & Reference \\
\hline Arkansas & 0 & 2.5 & 883 & 5 & Francis (1984) \\
Kentucky & 56 & 4.1 & 37037 & 3 & Wood et al. (1977) \\
Kentucky & 168 & $3.4^{\mathrm{a}}$ & 5978 & 5 & Wittwer et al. (1978) \\
Kentucky & 169 & 6.5 & 6050 & 5 & Wittwer et al. (1980) \\
Georgia & 22 & $9.2^{\mathrm{a}}$ & 26898 & 4 & Steinbeck et al. (1972) \\
Georgia & 22 & 5.8 & 3363 & 4 & Steinbeck (1999) \\
Georgia & 121 & $4.6^{\mathrm{b}}$ & 3472 & 4 & Dickmann et al. (1985) \\
Mississippi & 0 & 4.3 & 1200 & 5 & Tuskan and de la Cruz (1982) \\
Mississippi & 55 & 6.8 & 2252 & 3 & Tang and Land (1996) \\
Mississippi & 0 & 2.4 & 1076 & 5 & Krinard and Kennedy (1981) \\
South Carolina & 80 & $6.3^{\mathrm{b}}$ & 1333 & 3 & This study \\
Tennessee & 450 & 4.0 & 4000 & 1 & Tschaplinski et al. (1991) \\
Tennessee & 150 & 14.5 & 3333 & 3 & Van Miegroet et al. (1994)
\end{tabular}

${ }^{\mathrm{a}}$ Fresh biomass was multiplied by 0.5 to account for water content.

${ }^{\mathrm{b}}$ Grown with irrigation. 
ST66 belowground biomass production ranged from 0.6 to $2.0 \mathrm{Mg} \mathrm{ha}^{-1} \mathrm{yr}^{-1}$ in $\mathrm{C}$ and IF treatments, respectively; $\mathrm{S} 7 \mathrm{C} 15$ values also were within this range. Fine roots were the major belowground biomass component in all three genotypes (Fig. 2). Both irrigation (Dickmann et al., 1996) and fertilization (Kern et al., 2004) increased growth of fine roots in other studies. Our results are comparable to fine root biomass production of 1.2 (Friend et al., 1991) and 2.2 $\mathrm{Mg} \mathrm{ha}^{-1} \mathrm{yr}^{-1}$ (Heilman et al., 1994) in Washington. Study-to-study differences in stocking density and in the way fine roots are defined makes precise crossstudy comparisons difficult. Sycamore root biomass production was $3.1 \mathrm{Mg} \mathrm{ha}^{-1} \mathrm{yr}^{-1}$ in the IF treatment, with just over $50 \%$ of this in fine root biomass. This biomass production level is similar to that reported from a 7-year-old sycamore stand $\left(3.3 \mathrm{Mg} \mathrm{ha}^{-1} \mathrm{yr}^{-1}\right)$ planted on a similar site in Georgia (Steinbeck and Nwoboshi, 1980).

\subsection{Effects of resource amendments on biomass distribution}

We rejected our second hypothesis, which was that biomass accumulation favors shoots when trees are grown with high resource availability. Developmental effects largely accounted for any observed shifts in biomass fractions. Many studies of forest stands show that RMF declines with resource availability when chronologically equivalent stands are compared (Giardina et al., 2004; Landsberg and Gower, 1997; Sigurdsson et al., 2001; Waring and Ludlow, 2001). Our data agree with these results (Fig. 3B). However, other studies show RMF declines with age (Bernardo et al., 1998; Coleman et al., 2004a; Misra et al., 1998; Resh et al., 2003). Such developmental patterns are also observed in our study (Fig. 3A). To simply compare chronologically equivalent stands overlooks the importance of this developmental effect on RMF. Evaluating the effect of resource availability on RMF clearly requires that developmentally equivalent stands be compared. When we account for development by comparing $k$ among treatments (Table 3 ), we find similar or even greater allocation to roots with increasing resource availability. Therefore, we conclude that biomass accumulation does not favor shoots in developmentally equivalent stands grown with more favorable soil resources. Other attempts to compare developmentally equivalent stands also demonstrate that resource availability has little or no effect on relative belowground biomass accumulation in herbaceous plants (McConnaughay and Coleman, 1999), tree seedlings (Coleman et al., 1998; Drew and Ledig, 1980; Gebauer et al., 1996), or tree stands (Coleman et al., 2004a; King et al., 1999).

Allometric analysis may suffer from non-linearity between tissue types and use of insensitive tests for comparing differences in $k$ among treatment factors (Poorter and Nagel, 2000). An alternative is to test for differences in RMF across the size range. When taking this approach (Fig. 4), we similarly conclude that there are no differences among treatments. Developmental control of RMF is evident, and there is no evidence that increasing resources favor biomass accumulation in the shoot.

The proportion of fine-root to leaf production is more responsive to resource availability than that of perennial root to shoot tissues (Landsberg and Gower, 1997). We have tested these relationships here by comparing fine-root and leaf biomass. Our results show that development explains much of the variation in these relationships, as well, with little or no effect of resource availability (Table 3). The ephemeral biomass fractions we report do not directly measure production. In simply reporting biomass here, we have assumed that fine-root turnover is minimal. Although there is good evidence of low fine-root turnover early in stand establishment, turnover becomes an increasingly important factor in forest production with increasing stand age (Coleman et al., 2004a; Grier et al., 1981). Fine-root turnover is thought to be very sensitive to resource availability; however, even the direction of this response is controversial (Hendricks et al., 1993). We are currently monitoring fine-root turnover in these stands and will report those data separately. Our preliminary results suggest that the response to resource availability is complex and depends on a number of inherent and environmental factors including stand development.

Accounting for development is crucial to understanding processes controlling growth. Our results imply that many studies used in support of allocation shifts with increased resource availability simply report indirect effects of accelerated development. Studies of forest stands do not always include multiple sampling over a sufficient time span to account for development 
(e.g., Gower et al., 1992; Keyes and Grier, 1981; Linder and Axelsson, 1982). Understanding of belowground forest processes is hindered by lack of information on developmental patterns. We are aware of only a few studies monitoring forest developmental changes in belowground biomass or belowground production (Bernardo et al., 1998; Coleman et al., 2004a; Grier et al., 1981; Norby et al., 2004; Ovington, 1957; Vogt et al., 1987). Increased effort is necessary to adequately understand how resources and developmental factors interact in allocation to roots. Recent information on the response of soil respiration to fertilization and aboveground manipulations (Butnor et al., 2003; Högberg et al., 2001) suggest that root systems are highly responsive to environmental factors. Placing such results within a developmental context is important for modeling forest processes and predicting carbon dynamics in forests.

\section{Acknowledgements}

Funding was provided by the US Department of Energy-Savannah River Operations office through the USDA-Forest Service Savannah River and the Forest Service Southern Research Station under Interagency Agreement DE-IA09-76SR00056, Department of Energy Oak Ridge National Lab Interagency Agreement 00-IA-11330135-221, Southern Research Station Research Work Units 4103, 4104, 4154, 4155, 4505, 4703, and The Timber Company, Weyerhaeuser, Champion International, and Union Camp. Thanks to the many project technicians and staff at the USFS-Savannah River Forest Station, The University of Georgia, and Auburn University who made data collection possible. Thanks to Bernard Parresol, USFS Southern Research Station, for statistical consultation and advice.

\section{Appendix A}

Regression equations $^{\mathrm{a}}$ used for calculating biomass in 2002

\begin{tabular}{|c|c|c|c|c|c|c|c|c|c|c|}
\hline \multirow[t]{2}{*}{ Biomass fraction } & \multirow[t]{2}{*}{ Treatment } & \multicolumn{3}{|l|}{ ST66 } & \multicolumn{3}{|c|}{$\mathrm{S} 7 \mathrm{C} 15$} & \multicolumn{3}{|c|}{ Sycamore } \\
\hline & & $a$ & $b$ & $R^{2}$ & $a$ & $b$ & $R^{2}$ & $a$ & $b$ & $R^{2}$ \\
\hline \multirow[t]{4}{*}{ Branch } & C & 2.22 & 1.59 & 0.96 & 3.62 & 1.53 & 0.91 & 3.95 & 1.57 & 0.99 \\
\hline & I & 0.29 & 2.06 & 0.95 & 11.7 & 1.23 & 0.89 & 3.07 & 1.40 & 0.88 \\
\hline & $\mathrm{F}$ & 0.63 & 1.97 & 0.96 & 5.13 & 1.40 & 0.88 & 9.98 & 1.35 & 0.85 \\
\hline & IF & 1.10 & 1.73 & 0.99 & 0.08 & 2.35 & 0.97 & 0.08 & 2.60 & 0.89 \\
\hline \multirow[t]{4}{*}{ Bark } & C & 0.10 & 2.37 & 1.00 & 3.56 & 1.41 & 0.96 & 4.49 & 1.16 & 0.94 \\
\hline & I & 0.67 & 1.80 & 0.98 & 2.93 & 1.41 & 0.97 & 2.76 & 1.33 & 0.93 \\
\hline & F & 0.18 & 2.15 & 0.97 & 1.57 & 1.60 & 0.96 & 0.75 & 1.62 & 0.99 \\
\hline & IF & 0.28 & 1.99 & 0.99 & 2.61 & 1.45 & 0.99 & 5.94 & 1.16 & 0.86 \\
\hline \multirow[t]{4}{*}{ Wood } & C & 1.15 & 1.82 & 0.90 & 0.37 & 2.16 & 0.97 & 6.70 & 1.56 & 1.00 \\
\hline & I & 3.85 & 1.53 & 0.92 & 1.15 & 1.84 & 0.98 & 1.99 & 1.91 & 0.97 \\
\hline & $\mathrm{F}$ & 0.99 & 1.87 & 0.97 & 0.94 & 1.91 & 1.00 & 1.23 & 2.03 & 0.98 \\
\hline & IF & 0.70 & 2.02 & 0.99 & 0.41 & 2.15 & 0.99 & 0.86 & 2.11 & 0.92 \\
\hline \multirow[t]{4}{*}{ Stem } & $\mathrm{C}$ & 0.98 & 2.00 & 0.96 & 1.74 & 1.87 & 0.99 & 9.60 & 1.50 & 1.00 \\
\hline & I & 4.29 & 1.61 & 0.95 & 3.06 & 1.69 & 0.98 & 2.91 & 1.84 & 0.98 \\
\hline & $\mathrm{F}$ & 1.10 & 1.97 & 0.97 & 2.08 & 1.81 & 0.99 & 1.75 & 1.97 & 0.99 \\
\hline & IF & 1.00 & 2.01 & 1.00 & 1.18 & 1.97 & 0.99 & 1.58 & 2.00 & 0.92 \\
\hline \multirow[t]{4}{*}{ Total shoot ${ }^{\mathrm{b}}$} & C & 2.27 & 1.90 & 0.96 & 4.34 & 1.75 & 0.97 & 13.3 & 1.53 & 1.00 \\
\hline & I & 14.8 & 1.39 & 0.90 & 10.4 & 1.51 & 0.96 & 5.66 & 1.78 & 0.98 \\
\hline & $\mathrm{F}$ & 1.73 & 1.96 & 0.97 & 5.32 & 1.68 & 0.97 & 5.08 & 1.80 & 0.98 \\
\hline & IF & 1.86 & 1.93 & 1.00 & 1.10 & 2.06 & 1.00 & 3.47 & 1.92 & 0.85 \\
\hline
\end{tabular}


Appendix A (continued)

\begin{tabular}{|c|c|c|c|c|c|c|c|c|c|c|}
\hline \multirow[t]{2}{*}{ Biomass fraction } & \multirow[t]{2}{*}{ Treatment } & \multicolumn{3}{|l|}{ ST66 } & \multicolumn{3}{|c|}{ S7C15 } & \multicolumn{3}{|c|}{ Sycamore } \\
\hline & & $a$ & $b$ & $R^{2}$ & $a$ & $b$ & $R^{2}$ & $a$ & $b$ & $R^{2}$ \\
\hline \multirow[t]{4}{*}{ Stump } & C & 2.80 & 1.46 & 0.97 & 7.55 & 1.17 & 0.96 & 8.67 & 1.17 & 1.00 \\
\hline & I & 14.6 & 1.03 & 0.95 & 17.4 & 0.95 & 0.96 & 4.18 & 1.45 & 0.94 \\
\hline & $\mathrm{F}$ & 1.15 & 1.67 & 0.94 & 3.79 & 1.33 & 0.98 & 3.33 & 1.51 & 0.77 \\
\hline & IF & 2.96 & 1.40 & 0.97 & 3.59 & 1.33 & 0.84 & 1.44 & 1.65 & 0.91 \\
\hline \multirow[t]{4}{*}{ Coarse root } & $\mathrm{C}$ & 3.92 & 1.36 & 0.93 & 2.21 & 1.42 & 0.91 & 1.81 & 1.70 & 0.96 \\
\hline & I & 14.7 & 0.96 & 0.94 & 4.73 & 1.24 & 0.91 & 5.85 & 1.32 & 0.86 \\
\hline & $\mathrm{F}$ & 12.4 & 1.06 & 0.89 & 2.79 & 1.36 & 0.92 & 50.9 & 0.79 & 0.80 \\
\hline & IF & 9.30 & 1.13 & 0.97 & 0.98 & 1.63 & 0.99 & 0.02 & 2.61 & 0.84 \\
\hline \multirow[t]{4}{*}{ Total root ${ }^{\mathrm{c}}$} & $\mathrm{C}$ & 6.65 & 1.41 & 0.97 & 8.94 & 1.28 & 0.96 & 16.6 & 1.24 & 0.99 \\
\hline & I & 29.2 & 1.00 & 0.95 & 20.0 & 1.07 & 0.94 & 9.65 & 1.39 & 0.91 \\
\hline & $\mathrm{F}$ & 8.36 & 1.34 & 0.97 & 6.76 & 1.34 & 1.00 & 22.2 & 1.19 & 0.80 \\
\hline & IF & 10.9 & 1.26 & 0.98 & 3.92 & 1.47 & 0.95 & 1.86 & 1.74 & 0.86 \\
\hline
\end{tabular}

${ }^{\mathrm{a}}$ Regression equation were of the form $y=a x^{b}$ where $y$ is individual tree biomass ( $\mathrm{g}$ tree ${ }^{-1}$ ), $a$ and $b$ the model estimated parameters, and $x$ is DBH $(\mathrm{mm})$. All equations are significant $(P<0.01)$.

b Total shoot $=$ branch + bark + wood.

c Total root =stump + coarse root; fine roots could not be included in the equation due to sampling scheme.

\section{References}

Adams, P.R., Beadle, C.L., Mendham, N.J., Smethurst, P.J., 2003. The impact of timing and duration of grass control on growth of a young Eucalyptus globulus Labill. plantation. New For. 26, 147-165.

Aronsson, P., Perttu, K., 2001. Willow vegetation filters for wastewater treatment and soil remediation combined with biomass production. For. Chron. 77, 293-299.

Axelsson, E., Axelsson, B., 1986. Changes in carbon allocation patterns in spruce and pine trees following irrigation and fertilization. Tree Physiol. 2, 189-204.

Bernardo, A.L., Reis, M.G.F., Reis, G.G., Harrison, R.B., Firme, D.J., 1998. Effect of spacing on growth and biomass distribution in Eucalyptus camaldulensis, E. pellita, and E. urophylla plantations in southeastern Brazil. For. Ecol. Manage. 104, 1-13.

Blackmon, B.G., 1977. Cottonwood response to nitrogen related to plantation age and site. USDA Forest Service, Southern Research Station, Research Note SO-229, New Orleans, LA.

Blake, T.J., Sperry, J.S., Tschaplinski, T.J., Wang, S.S., 1996. Water relations. In: Stettler, R.F., Bradshaw, H.D., Heilman, P.E., Hinckley, T.M. (Eds.), Biology of Populus and its Implications for Management and Conservation. NRC Research Press, Ottawa, pp. 401-422.

Brown, K.R., van den Driessche, R., 2002. Growth and nutrition of hybrid poplars over 3 years after fertilization at planting. Can. J. For. Res. 32, 226-232.
Butnor, J.R., Johnsen, K.H., Oren, R., Katul, G.G., 2003. Reduction of forest floor respiration by fertilization on both carbon dioxideenriched and reference 17-year-old loblolly pine stands. Global Change Biol. 9, 849-861.

Cannell, M.G.R., Sheppard, L.J., Milne, R., 1988. Light use efficiency and woody biomass production of poplar and willow. Forestry 61, 125-136.

Chow, P., Rolfe, G.L., Motter, W.K., 1995. Chemical compositions of five 3-year-old hardwood trees. Wood Fiber Sci. 27, 319-326.

Coleman, M.D., Dickson, R.E., Isebrands, J.G., 1998. Growth and physiology of aspen supplied with different fertilizer addition rates. Physiol. Plant. 103, 513-526.

Coleman, M.D., Friend, A.L., Kern, C.C., 2004a. Carbon allocation and nitrogen acquisition in a developing Populus deltoides plantation. Tree Physiol. 24, 1347-1357.

Coleman, M.D., Coyle, D.R., Blake, J., Britton, K., Buford, M., Campbell, R.G., Cox, J., Cregg, B., Daniels, D., Jacobson, M., Johnsen, K., McDonald, T., McLeod, K., Nelson, E., Robison, D., Rummer, R., Sanchez, F., Stanturf, J., Stokes, B., Trettin, C., Tuskan, J., Wright, L., Wullschleger, S., 2004b. Production of short-rotation woody crops grown with a range of nutrient and water availability: establishment report and first-year responses. U.S. Department of Agriculture, Forest Service, Southern Research Station, Gen. Tech. Re SRS-72, Asheville, NC, pp. $1-21$.

Czapowskyj, M.M., Safford, L.O., 1993. Site preparation, fertilization, and 10-year yields of hybrid poplar on a clearcut forest site in eastern Maine, USA. New For. 7, 331-344. 
DeBell, D.S., Clendenen, G.W., Harrington, C.A., Zasada, J.C., 1996. Tree growth and stand development in short-rotation Populus plantings: 7-year results for two clones at three spacings. Biomass Bioenergy 11, 253-269.

Dickmann, D.I., Stuart, K.W., 1983. The Culture of Poplars in Eastern North America. Michigan State University Press, East Lansing, MI, 168 pp.

Dickmann, D.I., Steinbeck, K., Skinner, T., 1985. Leaf area and biomass in mixed and pure plantations of sycamore and black locust in the Georgia piedmont. For. Sci. 31, 509-517.

Dickmann, D.I., Nguyen, P.V., Pregitzer, K.S., 1996. Effects of irrigation and coppicing on above-ground growth, physiology and fine-root dynamics of two field-grown hybrid poplar clones. For. Ecol. Manage. 80, 163-174.

Drew, A.P., Ledig, F.T., 1980. Episodic growth and relative shoot:root balance in loblolly pine seedlings. Ann. Bot. 45, 143148.

Ericsson, T., Rytter, L., Linder, S., 1992. Nutritional dynamics and requirements of short rotation forests. In: Mitchell, C.P., FordRobertson, J.B., Hinckley, T., Sennerby-Forsse, L. (Eds.), Ecophysiology of Short Rotation Forest Crops. Elsevier Applied Science, London, pp. 35-65.

Fox, T.R., 2000. Sustained productivity in intensively managed forest plantations. For. Ecol. Manage. 138, 187-202.

Francis, J.K., 1984. Biomass accumulation by single- and multiplestemmed young sycamore. For. Sci. 30, 372-374.

Francis, J.K., Baker, J.B., 1981. Biomass and nutrient accumulation in a cottonwood plantation-the first four years. USDA Forest Service, Southern Research Station, Research Note SO-278, New Orleans, LA.

Friend, A.L., Scarascia-Mugnozza, G., Isebrands, J.G., Heilman, P.E., 1991. Quantification of 2-year-old hybrid poplar root systems -morphology, biomass, and ${ }^{14} \mathrm{C}$ distribution. Tree Physiol. 8, 109-119.

Gebauer, R.L.E., Reynolds, J.F., Strain, B.R., 1996. Allometric relations and growth in Pinus taeda: the effect of elevated $\mathrm{CO}_{2}$ and changing $\mathrm{N}$ availability. New Phytol. 134, 85-93.

Gebre, G.M., Kuhns, M.R., 1991. Seasonal and clonal variations in drought tolerance of Populus deltoides. Can. J. For. Res. 21, 910-916.

Giardina, C.P., Binckley, D., Ryan, M.G., Fownes, J.H., Senock, R.S., 2004. Belowground carbon cycling in a humid tropical forest decreases with fertilization. Oecologia 139, 545-550.

Gower, S.T., Vogt, K.A., Grier, C.C., 1992. Carbon dynamics of Rocky Mountain Douglas-fir: influence of water and nutrient availability. Ecol. Monogr. 62, 43-65.

Graham, R.L., Wright, L.L., Turhollow, A.F., 1992. The potential for short-rotation woody crops to reduce U.S. $\mathrm{CO}_{2}$ emissions. Climatic Change 22, 223-238.

Grier, C.C., Vogt, K.A., Keyes, M.R., Edmonds, R.L., 1981. Biomass distribution and above- and below-ground production in young and mature Abies amabilis zone ecosystems of the Washingtion Cascades. Can. J. For. Res. 11, 155-167.

Hansen, E.A., McLaughlin, R.A., Pope, P.E., 1988. Biomass and nitrogen dynamics of hybrid poplar on two different soils: implications for fertilization strategy. Can. J. For. Res. 18, 223-230
Harrington, C.A., Radwan, M.A., DeBell, D.S., 1997. Leaf characteristics reflect growth rates of 2-year-old Populus trees. Can. J. For. Res. 27, 1321-1325.

Heilman, P.E., Xie, F., 1993. Influence of nitrogen on growth and productivity of short-rotation Populus trichocarpa x Populus deltoides hybrids. Can. J. For. Res. 23, 1863-1869.

Heilman, P.E., Ekuan, G., Fogle, D.B., 1994. Above- and belowground biomass and fine roots of four-year-old hybrids of Populus trichocarba $\times$ P. deltoides and parental species in short rotation culture. Can. J. For. Res. 24, 1186-1192.

Hendricks, J.J., Nadelhoffer, K.J., Aber, J.D., 1993. Assessing the role of fine roots in carbon and nutrient cycling. Trends Ecol. Evol. 8, 174-178.

Högberg, P., Nordgren, A., Buchmann, N., Taylor, A.F.S., Ekblad, A., Hogberg, M.N., Nyberg, G., Ottosson-Lofvenius, M., Read, D.J., 2001. Large-scale forest girdling shows that current photosynthesis drives soil respiration. Nature 411, 789-792.

Hunt, R., 1978. Plant Growth Analysis. Edward Arnold Ltd., London, $67 \mathrm{pp}$.

Kauter, D., Lewandowski, I., Claupein, W., 2003. Quantity and quality of harvestable biomass from Populus short rotation coppice for solid fuel use: a review of the physiological basis and management influences. Biomass Bioenergy 24, 411-427.

Kern, C.C., Friend, A.L., Johnson, J.M.-F., Coleman, M.D., 2004. Fine root dynamics in a developing Populus deltoides plantation. Tree. Physiol. 24, 651-660.

Keyes, M.R., Grier, C.C., 1981. Above- and below-ground net production in 40-year-old Douglas-fir stands on low and high productivity sites. Can. J. For. Res. 11, 599-605.

King, J.S., Albaugh, T.J., Allen, H.L., Kress, L.W., 1999. Stand-level allometry in Pinus taeda as affected by irrigation and fertilization. Tree Physiol. 19, 769-778.

Kleinbaum, D.G., Kupper, L.L., 1978. Applied Regression Analysis and Other Multivariable Methods. Duxbury Press, Boston, MA, USA, $556 \mathrm{pp}$.

Kozlowski, T.T., Kramer, P.J., Pallardy, S.G., 1991. The Physiological Ecology of Woody Plants. Academic Press, San Diego, CA, 796 pp.

Kramer, P.J., 1983. Water Relations of Plants. Academic Press, New York, 489 pp.

Krinard, R.M., Kennedy, H.E.J., 1981. Growth and yields of 5-yearold planted hardwoods on sharkey clay soil, USDA Forest Service, Southern Forest Experiment Station Research Note SO-271, pp. 3.

Landsberg, J.J., 1986. Physiological Ecology of Forest Production. Academic Press, London, 198 pp.

Landsberg, J.J., Gower, S.T., 1997. Applications of Physiological Ecology to Forest Management. Academic Press, New York, 354 pp.

Linder, S., 1989. Nutritional Control of Forest Yield: Nutrition of Trees. The Marcus Wallenberg Foundation, Falun, Sweden, pp. 62-87.

Linder, S., Axelsson, B., 1982. Changes in carbon uptake and allocation patterns as a result of irrigation and fertilization in a young Pinus sylvestris stand. In: Waring, R.H. (Ed.), Carbon Uptake and Allocation in Subalpine Ecosystems as a Key to 
Management. For. Res. Lab., Oregon State University, Corvallis, OR, pp. 38-44.

Littell, R.C., Milliken, G.A., Stroup, W.W., Wolfinger, R.D., 1996. SAS System for Mixed Models. SAS Institute Inc., Cary, NC, USA, 633 pp.

Lockaby, B.G., Clawson, R.G., Baker, T., 1997. Response of three hardwood species to irrigation and fertilization on an upland site. S. J. Appl. For. 21, 123-129.

McConnaughay, K.D.M., Coleman, J.S., 1999. Biomass allocation in plants: ontogeny or optimality? A test along three resource gradients. Ecology 80, 2581-2593.

McLaughlin, R.A., Hansen, E.A., Pope, P.E., 1987. Biomass and nitrogen dynamics in an irrigated hybrid poplar plantation. For. Ecol. Manage. 18, 169-188.

Misra, R.K., Turnbull, C.R.A., Cromer, R.N., Gibbons, A.K., LaSala, A.V., 1998. Below- and above-ground growth of Eucalyptus nitens in a young plantation. I. Biomass. For. Ecol. Manage. 106, 283-293.

Myers, B.J., Theiveyanathan, S., O’Brien, N.D., Bond, W.J., 1996. Growth and water use of Eucalyptus grandis and Pinus radiata plantations irrigated with effluent. Tree Physiol. 16, 211219.

Netzer, D.A., Tolsted, D.N., Ostry, M.E., Isebrands, J.G., Riemenschneider, D.E., Ward, K.T., 2002. Growth, yield, and disease resistance of 7- to 12-year old poplar clones in the North Central United States. U.S. Department of Agriculture, Forest Service, General Technical Report NC-229, North Central Research Station, St. Paul, MN, pp. 31.

Newman, L.A., Strand, S.E., Choe, N., Duffy, J., Ekuan, G., Ruszaj, M., Shurtleff, B.B., Wilmoth, J., Heilman, P., Gordon, M.P., 1997. Uptake and biotransformation of trichloroethylene by hybrid poplars. Environ. Sci. Technol. 31, 1062-1067.

Norby, R.J., Ledford, J., Reilly, C.D., Miller, N.E., O’Neill, E.G., 2004. Fine-root production dominates response of a deciduous forest to atmospheric $\mathrm{CO}_{2}$ enrichment. Proc. Natl. Acad. Sci. 101, 9689-9693.

Ovington, J.D., 1957. Dry-matter production by Pinus sylvestris L. Ann. Bot. 21, 287-314.

Parresol, B.R., 1999. Assessing tree and stand biomass: a review with examples and critical comparisons. For. Sci. 45, 573593.

Pereira, J.S., Linder, S., Araujo, M.C., Pereira, H., Ericsson, T., Borralho, N., Leal, L.C., 1989. Optimization of biomass production in Eucalyptus globulus plantations: a case study. In: Pereira, J.S., Landsberg, J.J. (Eds.), Biomass Production by Fast-Growing Trees. Kluwer, Dordrecht, The Netherlands, pp. 101-121.

Poorter, H., Nagel, O., 2000. The role of biomass allocation in the growth response of plants to different levels of light, $\mathrm{CO}_{2}$, nutrients and water: a quantitative review. Aust. J. Plant Physiol. 27, 595-607.

Reed, D., Tomé, M., 1998. Total aboveground biomass and net dry matter accumulation by plant component in young Eucalyptus globulus in response to irrigation. For. Ecol. Manage. 103, 2132.

Resh, S.C., Battaglia, M., Worledge, D., Ladiges, S., 2003. Coarse root biomass for eucalypt plantations in Tasmania, Australia: sources of variation and methods for assessment. Trees 17, 389399.

Rogers, V.A., 1990. Soil Survey of Savannah River Plant Area, Parts of Aiken, Barnwell, and Allendale Counties, South Carolina. USDA Soil Conservation Service, Washington, DC.

Samuelson, L., Stokes, T., Cooksey, T., McLemore, P., 2001. Production efficiency of loblolly pine and sweetgum in response to four years of intensive management. Tree Physiol. 21, 369-376.

Samuelson, L.J., 1998. Influence of intensive culture on leaf net photosynthesis and growth of sweetgum and loblolly pine seedlings. For. Sci. 44, 308-316.

Sands, R., Mulligan, D.R., 1990. Water and nutrient dynamics and tree growth. For. Ecol. Manage. 30, 91-111.

Sedjo, R.A., 1997. The economics of forest-based biomass supply. Energy Policy 25, 559-566.

Shock, C.C., Feibert, B.G., Seddigh, M., Saunders, L.D., 2002. Water requirements and growth of irrigated hybrid poplar in a semi-arid environment in eastern Oregon. West. J. Appl. For. 17, $46-53$.

Sigurdsson, B.D., Thorgeirsson, H., Linder, S., 2001. Growth and dry-matter partitioning of young Populus trichocarpa in response to carbon dioxide concentration and mineral nutrient availability. Tree Physiol. 21, 941-950.

Stanton, B., Eaton, J., Johnson, J., Rice, D., Schuette, B., Moser, B., 2002. Hybrid poplar in the Pacific Northwest: the effects of market-driven management. J. For. 100, 28-33.

Stanturf, J.A., van Oosten, C., Netzer, D.A., Coleman, M.D., Portwood, C.J., 2001. Ecology and silviculture of poplar plantations. In: Dickmann, D.I., Isebrands, J.G., Eckenwalder, J.E., Richardson, J. (Eds.), Poplar Culture in North America. National Research Courcil, Ottawa, Canada, pp. 153-206.

Steinbeck, K., 1999. Woody biomass production of sweetgum and American sycamore harvested on different cutting cycles. In: Hartsough, B.R. (Ed.), Proceedings of the Second Conference Short-Rotation Woody Crops Operations Working Group, 25-27 August 1998, Vancouver, WA, USA. Davis, University of California, CA, USA, pp. 29-32.

Steinbeck, K., Nwoboshi, L.C., 1980. Rootstock mass of coppiced Platanus occidentalis as affected by spacing and rotation length. For. Sci. 26, 545-547.

Steinbeck, K., McAlpine, R.G., May, J.T., 1972. Short rotation culture of sycamore: a status report. J. For. 70, 210-213.

Switzer, G.L., Nelson, L.E., Baker, J.B., 1976. Accumulation and distribution of dry matter and nutrients in Aigeiros poplar plantations. In: Thielges, B.A., Land, Jr., S.B. (Eds.), Symposium on Eastern Cottonwood and Related Species. Division of Continuing Education, Lousiana State University, Baton Rouge, LA, Greenville, MS, pp. 359-369.

Tang, Z., Land, S.B., 1996. Early growth, leaf development, and dryweight production of sycamore rooted cuttings. Biomass Bioenergy 10, 221-229.

Ter-Mikaelian, M.T., Korzukhin, M.D., 1997. Biomass equations for sixty-five North American tree species. For. Ecol. Manage. 97, 1-24.

Thornton, F.C., Bock, B.R., Behel, A.D., Houston, A., Tyler, D.D., 2000. Utilization of waste materials to promote hardwood tree growth. S. J. Appl. For. 24, 230-237. 
Tomé, R., Tomé, J.A., Araújo, M.C., Pereira, J.S., 1994. Intraspecific competition in irrigated and fertilized eucalypt plantations. For. Ecol. Manage. 69, 211-218.

Tschaplinski, T.J., Norby, R.J., Johnson, D.W., Todd, D.E., 1991. Biomass and soil nitrogen relationships of a one-year-old sycamore plantation. Soil. Sci. Soc. Am. J. 55, 841-847.

Tuskan, G.A., de la Cruz, A.A., 1982. Solar input and energy storage in a five-year-old American sycamore plantation. For. Ecol. Manage. 4, 191-198.

van den Driessche, R., Rude, W., Martens, L., 2003. Effect of fertilization and irrigation on growth of aspen (Populus tremuloides Michx.) seedlings over three seasons. For. Ecol. Manage. 186, 381-389.

Van Miegroet, H., Norby, R.J., Tschaplinski, T.J., 1994. Nitrogen fertilization strategies in a short-rotation sycamore plantation. For. Ecol. Manage. 64, 13-24.

Vogt, K.A., Vogt, D.J., Moore, E.E., Fatuga, B.A., Redlin, M.R., Edmonds, R.L., 1987. Conifer and angiosperm fine-root biomass in relation to stand age and site productivity in Douglas-fir forests. J. Ecol. 75, 857-870.

Waring, R.H., Schlesinger, W.H., 1985. Forest Ecosystems. Academic Press, Orlando, 340.

Waring, R.H., Ludlow, A., 2001. Ecophysiology of Forests. In: Evans, J. (Ed.), Handbook of Forestry. Blackwell Science, London.

Wittwer, R.F., Immel, M.J., Ellingsworth, F.R., 1980. Nutrient uptake in fertilized plantations of American sycamore. Soil. Sci. Soc. Am. J. 44, 606-610.

Wittwer, R.F., King, R.H., Clayton, J.M., Hinton, O.W., 1978. Biomass yield of short-rotation American sycamore as influenced by site, fertilizers, spacing, and rotation age. South. J. Appl. For. 2, 15-19.

Wood, B.W., Wittwer, R.F., Carpenter, S.B., 1977. Nutrient element accumulation and distribution in an intensively cultured American sycamore plantation. Plant Soil 48, 417433. 